Open Access

Res. Agric. Livest. Fish.

Research Article

Vol. 2, No. 3, December 2015: 453-457

\title{
IDENTIFICATION OF BACTERIAL AGENTS FROM THE FAECAL SAMPLES OF DIARRHOEIC SHEEP AND THEIR ANTIBIOTIC SENSITIVITY
}

\section{Md. Nuruzzaman Munsi, Md. Ershaduzzaman, Md. Osman Gani, Md. Moinuddin Khanduker and Md. Shahin Alam}

Goat and Sheep Production Research Division, Bangladesh Livestock Research Institute, Savar, Dhaka-1341, Bangladesh

*Corresponding author: Md. Nuruzzaman Munsi; E-mail: nzaman_blri@yahoo.com

ARTICLE INFO

Received

23.11.2015

Accepted

09.12 .2015

Online

21.12.2015

Key words

Bacteria

Diarrhoea

Sheep

Antibiotic

Sensitivity
ABSTRACT

To cite this article: Munsi M N, M Ershaduzzaman, M O Gani, M M Khanduker and M S Alam , 2015. Identification of bacterial agents from the faecal samples of diarrhoeic sheep and their antibiotic sensitivity. Res. Agric. Livest. Fish. 2 (3): 453-457.

The current study was carried out to identify the bacterial species in the faecal samples of 20 diarrhoeic sheep and to observe their sensitivity to different antibiotics. This investigation was performed by collecting diarrhoeal samples from the sheep $(n=20)$ under goat and sheep research farm of Bangladesh Livestock Research Institute (BLRI), Savar, Dhaka, Bangladesh. The average age and body weight of the animals were 25 days and $2.5 \mathrm{~kg}$ respectively. Of the bacteria responsible for diarrhoea in case of sheep, Escherichia coli alone was found in 6 samples (30\%), Escherichia coli combined with Proteus mirabilis was found in 12 samples $(60 \%)$, and no bacteria could be detected in 2 of the 20 samples tested. Both the bacteria were highly sensitive to ceftriaxone, and moderately sensitive to ciprofloxacin and gentamicin. It could be stated that ceftriaxone is the antibiotic of first choice for the treatment of diarrhoea in sheep, where Escherichia coli is suspected to be the principal causal agent of diarrhoea. 


\section{INTRODUCTION}

Diarrhoea characterized by an increased frequency, fluidity, or volume of faecal excretion is a major problem in the farm animals. It is caused by a wide range of microbial, parasitic and environmental factors namely-bacteria, virus, helminths, protozoa, toxic substances, sands, lush pasture, overfeeding, overcrowding, poor sanitation, inadequate intake of colostrum, poor quality colostrum, poor quality milk replacers, feeds difficult to digest, etc. On the basis of literature the bacterial agents causing diarrhoea in sheep are Escherichia coli, Salmonella spp. and Clostridium perfringens, where Proteus spp., and some other species of bacteria may be associated in some cases (Rahaman, 1995).

According to Hindson and Winter (2002), a combination of reduced reabsorption from the lumen of the intestine, and increased fluid loss through damaged mucosa into the intestine is found in many forms of both gastroenteritis and inflammatory change in the lower intestine. Such a condition ranges from bacterial infections such as E. coli and Salmonella to parasitic diseases such as coccidiosis and parasitic gastroenteritis. Diarrhoea or enteritis, to a greater extent, is related with clostridial diseases. These clostridial diseases of sheep have been recognized clinically for over 200 years, but not until the end of the nineteenth century did their bacterial nature start to be unraveled, a process that continued over the next 50 years (Sterne, 1981). Even during the 1990s, new information came to light as the importance of Clostridium sordellii as a cause of abomasitis and enteritis in all ages of sheep was established (Lewis and Naylor, 1998). The haemorrhagic enteritis affecting lambs in the first few days of life is caused by C. perfringens types (either beta or beta 2 toxin) or $\mathrm{C}$, and differs from lamb dysentery only in the gross pathology and being marginally less acute, affecting lambs up to 3 weeks of age (Lewis, 2007).

$E$. coli is a major cause of diarrhoea in calves, piglets and lambs, and the term 'colibacillosis' is commonly used. It causes huge economic loss in this age group of animals (Radostits et al., 2000). However, selection of suitable antibiotics is a good strategy for successful treatment of bacterial diarrhoea. But all antibiotics are not always useful for the treatment of diarrhoea because of development of antibiotic resistance. So, the present study was carried out to identify the bacterial species in the faecal samples of diarrhoeic sheep and to observe their sensitivity to different antibiotics.

\section{MATERIALS AND METHODS}

This investigation was performed in the bacteriological laboratory of Bangladesh Livestock Research Institute (BLRI) by collecting diarrhoeal samples from the sheep $(n=20)$ in BLRI goat and sheep research farm. The average age and body weight of the animals were 25 days and $2.5 \mathrm{~kg}$, respectively. The duration of the experiment was from August, 2010 to May, 2011.

\section{Sample collection}

The faecal samples were collected aseptically into stool containers directly from the rectum with the help of small polybags.

\section{Laboratory tests for identification of bacteria}

The collected samples were then allowed for culture in bacteriological media (nutrient agar, EMB agar, SS agar, Blood agar, Mac Conkey agar), Gram's staining and biochemical tests (Methyl Red test, Indole test, Catalase test, etc) for isolation and identification of the bacterial species.

\section{Antibiotic sensitivity test}

The antibiotic sensitivity test was done by using disc diffusion method (Cowan and Steel, 1965). The commercially available antibiotic discs such as, oxytetracycline, gentamicin, amoxycillin, penicillin G, cloxacillin, sulphamethoxazole, streptomycin, ciprofloxacin and ceftriaxone were used to know the sensitivity of Escherichia coli and Proteus mirabilis to these drugs. 


\section{RESULTS AND DISCUSSION}

The isolates were identified as Escherichia coli on the basis of morphology (Gram negative rod), cultural characteristics (Green metallic sheen on EMB agar as in fig.1) and biochemical characteristics and Proteus mirabilis on the basis of morphology (Gram negative rod), cultural characteristics (Swarming growth on Mac Conkey agar as in fig. 2 and Brilliant Green Agar) and biochemical characteristics. Among the different kinds of bacteria responsible for diarrhoea in sheep, only Escherichia coli was found in 6 samples (30\%), Escherichia coli alone combined with Proteus mirabilis was found in 12 samples $(60 \%)$, and no bacteria were found in 2 of the 20 samples tested (Table 1).

Both the bacteria were highly sensitive to ceftriaxone, and moderately sensitive to ciprofloxacin and gentamicin (Table 2). The inhibition zones, in case of ceftriaxone, were $29 \mathrm{~mm}$ for Escherichia coli and $27 \mathrm{~mm}$ for Proteus mirabilis while these zones were $17 \mathrm{~mm}$ for Escherichia coli and $21 \mathrm{~mm}$ for Proteus mirabilis in case of ciprofloxacin and $17 \mathrm{~mm}$ for both Escherichia coli and Proteus mirabilis in case of gentamicin (Table 2). These bacteria were found resistant to other antibiotics used in the sensitivity test (Table 2). Wang et al. 2014 noticed decreased susceptibility of $P$. mirabilis in Taiwan to some broad spectrum antibiotics, including 3rd-generation cephalosporins and ciprofloxacin, whereas Kwiecińska-Piróg et al. 2013 found that in most of the tested concentrations, ciprofloxacin was more efficient than ceftazidime against the $P$. mirabilis biofilm. They became able to prove that the efficiency of antibiotics against $P$. mirabilis biofilm depends on its maturity and strains' origin.

Bacterial resistance to a particular antibiotic might occur due to use of that antibiotic for a longer period of time. The present study revealed that $E$. coli isolates were resistant to several antibiotics like penicillin $G$, amoxycillin, cloxacillin, streptomycin and oxytetracycline. These findings are in support of Ershaduzzaman et al. 2007, Tadesse et al. 2012. But Islam et al. 2007 found streptomycin as a sensitive antibiotic to E. coli which contradicts the present findings. However, this might happen due to strain variation of $E$. coli.

In this investigation the highest sensitivity was recorded for ceftriaxone because it is a new generation of cephalosporin and has not been used by the physician for long time.

Table 1. Prevalance of bacteria found in the diarrhoeal samples of sheep

\begin{tabular}{|lccc|}
\hline Bacteria Found & $\begin{array}{c}\text { Total Number of } \\
\text { Samples Tested }\end{array}$ & No. of Positive Samples & Percentage \\
\hline Escherichia coli and & 20 & 12 & $60 \%$ \\
Proteus mirabilis. & & 6 & $30 \%$ \\
Escherichia a coli & 20 & 2 & $10 \%$ \\
No bacteria & 20 & & 30 \\
\hline
\end{tabular}

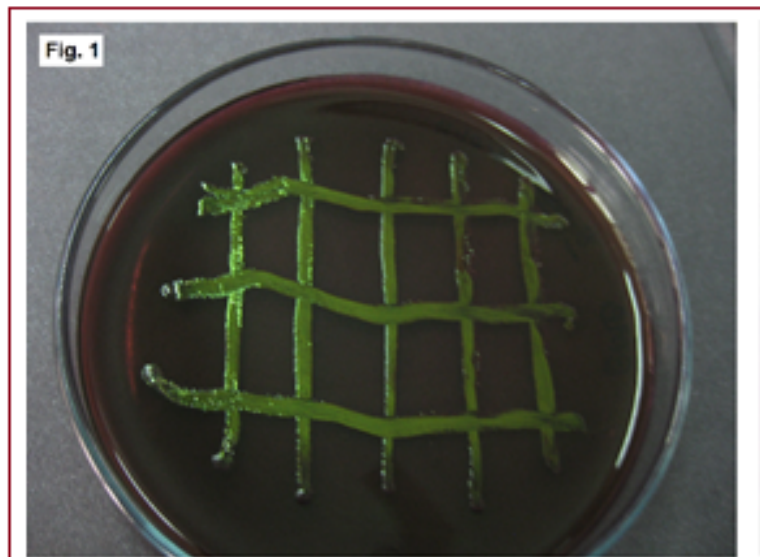

Figure 1. Growth of E. coli in EMB agar with Metallic sheen.

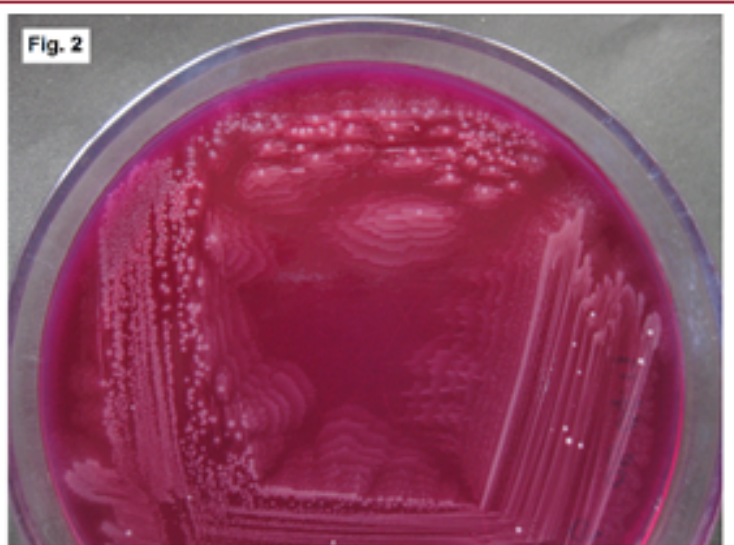

Figure 2. Swarming growth of Proteus mirabinis in MacConkey agar. 
Table 2. Inhibition zones produced by antibiotics used against Escherichia coli and Proteus mirabilis in the sensitivity test.

\begin{tabular}{|c|c|c|c|}
\hline $\begin{array}{l}\text { Antibiotics discs } \\
\text { used }\end{array}$ & Bacterial species & Zone of inhibition & Result \\
\hline \multirow[t]{2}{*}{ Oxytetracycline } & Escherichia coli & $7 \mathrm{~mm}$ & Resistant \\
\hline & Proteus mirabilis & $0 \mathrm{~mm}$ & Resistant \\
\hline \multirow[t]{2}{*}{ Gentamicin } & Escherichia coli & $17 \mathrm{~mm}$ & Moderately sensitive \\
\hline & Proteus mirabilis & $17 \mathrm{~mm}$ & Moderately sensitive \\
\hline \multirow[t]{2}{*}{ Amoxycillin } & Escherichia coli & $0 \mathrm{~mm}$ & Resistant \\
\hline & Proteus mirabilis & $7 \mathrm{~mm}$ & Resistant \\
\hline \multirow[t]{2}{*}{ Penicillin G } & Escherichia coli & $0 \mathrm{~mm}$ & Resistant \\
\hline & Proteus mirabilis & $0 \mathrm{~mm}$ & Resistant \\
\hline \multirow[t]{2}{*}{ Cloxacillin } & Escherichia coli & $0 \mathrm{~mm}$ & Resistant \\
\hline & Proteus mirabilis & $0 \mathrm{~mm}$ & Resistant \\
\hline \multirow[t]{2}{*}{ Sulphamethoxazole } & Escherichia coli & $0 \mathrm{~mm}$ & Resistant \\
\hline & Proteus mirabilis & $0 \mathrm{~mm}$ & Resistant \\
\hline \multirow[t]{2}{*}{ Streptomycin } & Escherichia coli & $0 \mathrm{~mm}$ & Resistant \\
\hline & Proteus mirabilis & $0 \mathrm{~mm}$ & Resistant \\
\hline \multirow[t]{2}{*}{ Ciprofloxacin } & Escherichia coli & 17 mm & Moderately sensitive \\
\hline & Proteus mirabilis & $21 \mathrm{~mm}$ & Highly sensitive \\
\hline \multirow[t]{2}{*}{ Ceftriaxone } & Escherichia coli & $29 \mathrm{~mm}$ & Highly sensitive \\
\hline & Proteus mirabilis & 27 mm & Highly sensitive \\
\hline
\end{tabular}

N.B.: The interpretation was done as resistant $(\leq 10 \mathrm{~mm})$, less sensitive $(11-14 \mathrm{~mm})$, moderately sensitive $(15-18 \mathrm{~mm})$ and highly sensitive $(\geq 19 \mathrm{~mm}$ ) except penicillin $\mathrm{G}$, where zone of inhibition for resistance range is $\leq 28 \mathrm{~mm}$ according to KirbyBauer Method.
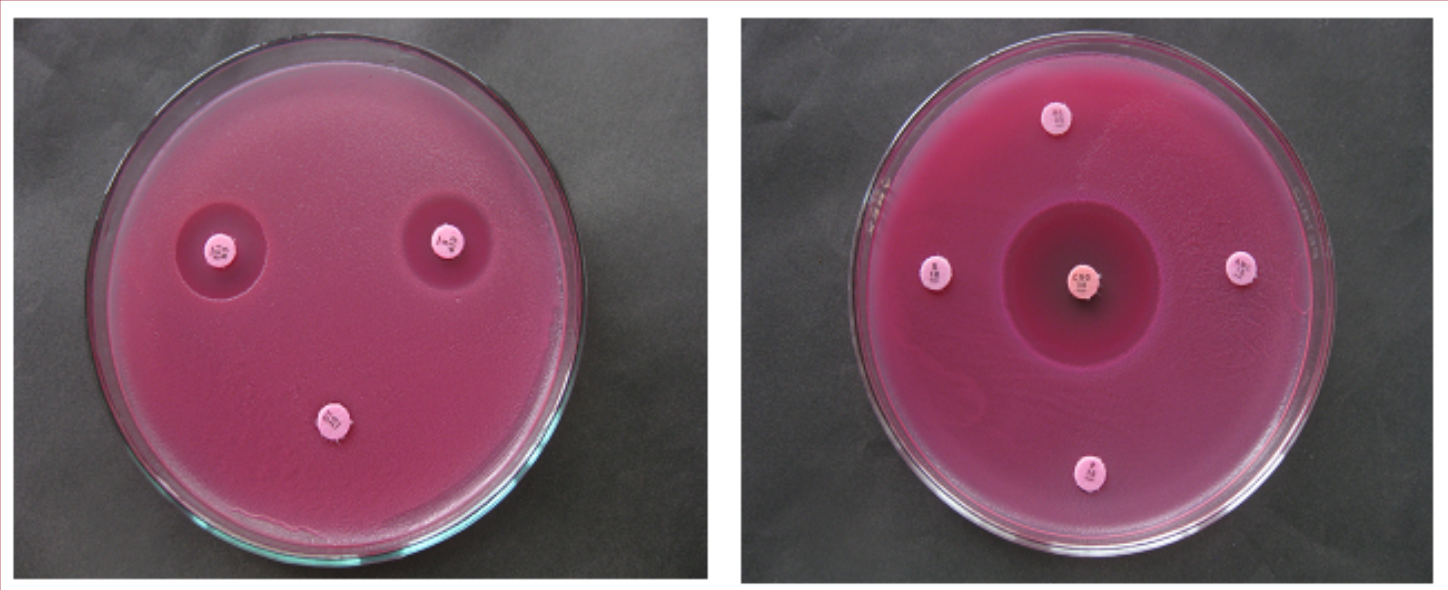

Figure 3. Production of clear zone of inhibition by Ceftriaxone (at the right-central), Ciprofloxacin (at the left-left one), Gentamicin (at the left-right one) of $E$. coli in Mac Conkey agar.

\section{CONCLUSION}

In conclusion, it might be stated that ceftriaxone is the antibiotic of first choice, and ciprofloxacin and gentamicin are the antibiotics of second choice to be used for the treatment of diarrhoea in sheep, where Escherichia coli is suspected to be principal causal agent of diarrhoea. 


\section{REFERENCES}

1. Cowan ST and Steel KJ, 1965. Manual for the Identification of Medical Bacteria. Cambridge University Press, Cambridge.

2. Ershaduzzaman M, Taimur MJFA and Munsi MN, 2007. Bacteriopathology of Pneumoenteritis and Antibiotic Sensitivity of the Organisms Isolated from Black Bengal Kids Affected with the Diseases. Bangladesh Journal of Livestock Research, 14: 59-66.

3. Hindson JC and Winter Agnes C., 2002. Diarrhoea. In Manual of Sheep Diseases, $2^{\text {nd }}$ edn., Blackwell Science Ltd., pp 90-95.

4. Islam MR, Ershaduzzaman M, Faruque MH,Munsi MN, Alam MS and Talukder MAI, 2007. Isolation and Identification of the Organisms of Sub-clinical Mastitis of Sheep and Goats in BLRI Sheep and Goat Farm. Proceedings of Annual Research Review Workshop-2007, Bangladesh Livestock Research Institute, Savar, Dhaka 1341, pp: 60-61.

5. Kwiecińska-Piróg J, Skowron K, Zniszczol K, and Gospodarek E, 2013. The Assessment of Proteus mirabilis Susceptibility to Ceftazidime and Ciprofloxacin and the Impact of These Antibiotics at Subinhibitory Concentrations on Proteus mirabilis Biofilms. BioMed Research International, Article ID 930876, doi.org/10.1155/2013/930876.

6. Lewis CJ, 2007. Clostridial Diseases. In Diseases of Sheep, $4^{\text {th }}$ edn., Blackwell Publishing Ltd., pp 156-59.

7. Lewis CJ and Naylor RD, 1998. Sudden Death in Sheep Associated with Clostridium sordellii. Veterinary Record, 142: 417-21

8. Radostits OM, Gay CC, Blood DC and Hinchcliff KW, 2000. Diseases Caused by Bacteria - III. In Veterinary Medicine, $9^{\text {th }}$ edn., pp 779-83.

9. Rahaman M, 1995. Systemic Bacteriology. In Bacteriology, $1^{\text {st }}$ edn., p 134.

10. Sterne M, 1981. Clostridial Infections. British Veterinary Journal, 137:443-54.

11. Tadesse DA, Zhao S, Tong E, Ayers S, Singh A, Bartholomew MJ, and McDermott PF, 2012. Antimicrobial Drug Resistance in Escherichia coli from Humans and Food Animals, United States, 1950-2002. Emerging Infectious Diseases, 18(5): http://dx.doi.org/10.3201/eid1805.111153

12. Wang J-T, Chen P-C, Chang S-C, Shiau Y-R, Wang H-Y, Lai J-F, Huang I-W, Tan M-C, Lauderdale T-LY, and TSAR Hospitals, 2014. Antimicrobial susceptibilities of Proteus mirabilis: a longitudinal nationwide study from the Taiwan surveillance of antimicrobial resistance (TSAR) program. BMC Infectious Diseases, 14: 486. 